\title{
SEASONAL CHANGES OF VITAMIN A AND BETA-CAROTENE LEVELS OF SERUM AND LIVER IN HOLSTEIN COWS
}

\author{
Ghadrdan Mashhadi A. ${ }^{1}$, Taghipour Bazargani $T^{2}$., Bokaie $S^{2}$. , Poorkabireh M.A. ${ }^{2}$ \\ ${ }^{1}$ Faculty of Veterinary Medicine, Sh. Chamran University, Ahvaz, Iran \\ ${ }^{2}$ Faculty of Veterinary Medicine, Tehran University, Teharan, Iran
}

Vitamin A is one of the fat-soluble vitamins. Because of its particular role in different tissues and organs in deficiency conditions various clinical signs are seen. In addition, sometimes the marginal deficiency is present that clinical signs are not visible but performance defects, such as infertility is seen.

In present study seasonal changes of serum vitamin A and beta-carotene levels in 342 cows and liver levels of vitamin A and beta-carotene in 371 cows was investigated in a slaughterhouse around Tehran (Iran) between November1996- October 1997. We also selected animals from two sexes and divided them to the 5 age groups ( less than 2, 2-3, 3-4, 4-5 years old and more than 5 years old). A simple and cheep method (spectrophotometry) was used for measuring vitamin A and beta-carotene. The results were analyzed statistically by multifactorial repeated measures (ANOVA), multiple-regression and Pearson's correlation. Results showed that the values of mean of liver and serum vitamin A levels and liver levels of beta-carotene were within normal range $(189.3 \mu \mathrm{g} / \mathrm{gr}, 67.2 \mu \mathrm{g} / \mathrm{dl}$ and $21.1 \mu \mathrm{g} / \mathrm{gr}$ respectively). These values in different seasons, age groups and two sexes were normal, too. While serum levels of beta-carotene concentration $(85.5 \mu \mathrm{g} / \mathrm{dl})$ was lower than normal range.

Results also showed that liver vitamin A and liver and serum beta-carotene in female were significantly more than male's but there wasn't there wasn't significant difference between male and female serum vitamin A.

In different age groups significant difference was seen only in liver vitamin A (maximum in cows more than 5 years old and minimum in cows less than two years old). These findings are just in accordance with results of previous studies.

Serum vitamin A in winter and serum beta-carotene in autumn was significantly higher than other seasons. These finding are different with similar study that performed in Poland. There wasn't significant difference between seasons liver vitamin A and beta-carotene.

\section{Reference}

Iwanska S. et al(1992). Beta-carotene and vitamin A content in blood plasma and the liver of slaughter cows in different seasons of the year. Vet. Bull., 82: 3714

Suzuki J. and Katoh N.(1990). A simple and cheep method for measuring serum vitamin A in cattle- using only a spectrophotometer. Jpn. J. Vet. Sci., 52: 1281-1283 